Research Article

\title{
Comet and cytogenetic tests as tools for evaluating genomic instability in seeds of Oryza sativa L. and Phaseolus vulgaris L. from gene banks
}

\author{
Alisson F. Dantas ${ }^{1}$, Renata M. Lopes ${ }^{2}$, Maria L. Fascineli ${ }^{1}$, Solange C.B.R. José ${ }^{3}$, Juliano G. Pádua ${ }^{3}$, Marcos \\ A. Gimenes ${ }^{3}$ and Cesar K. Grisolia ${ }^{1}$ iD \\ ${ }^{1}$ Laboratório de Genética Toxicológica, Departamento de Genética e Morfologia, Instituto de Ciências \\ Biológicas, Universidade de Brasília, Brasília, DF, Brazil. \\ ${ }^{2}$ Departmento de Botânica, Instituto de Ciências Biológicas, Universidade de Brasília, Brasília, DF, Brazil. \\ ${ }^{3}$ Embrapa Recursos Genéticos e Biotecnologia, Brasília, DF, Brazil.
}

\begin{abstract}
This study aimed to assess the feasibility of comet and cytogenetic tests as tools for evaluating genomic instability in seeds of Oryza sativa L. (rice) and Phaseolus vulgaris (beans) L. from gene banks. Rice and beans were exposed to methyl methanesulfonate (MMS) as a reference DNA damaging agent. Seeds of two accessions of rice and beans were obtained from Embrapa Rice and Beans - Brazil. Seed groups were imbibed in three concentrations of MMS for three periods of time to carry out cytogenetic tests, and for one period for the comet test. At concentrations of 10 and $15 \mathrm{mg} / \mathrm{L}, \mathrm{MMS}$ induced cytotoxic and/or mutagenic effects in the meristematic cells of roots from all the accessions of both species. In the comet test, MMS induced genotoxic effects at all the concentrations in the evaluated accessions of rice and beans, except in one accession of beans at the lowest concentration $(5 \mathrm{mg} / \mathrm{L})$. Both species showed sensitivity to MMS. The comet test can be proposed for the measurement of genomic instability in accessions of rice and beans in gene banks, as being more sensitive than the cytogenetic tests used.
\end{abstract}

Keywords: Oryza sativa L., Phaseolus vulgaris L., methyl methanesulfonate, cytogenetic test, comet test.

Received: January 23, 2017; Accepted: September 11, 2017.

\section{Introduction}

Common rice, Oryza sativa L. (Poaceae family), and common bean, Phaseolus vulgaris L. (Fabaceae family) play an important role in the nutrition of various countries, and in Brazil they are the main components of the staple diet (Barbosa, 2007). Common rice is an annual gramineous species of Asiatic origin, which can adapt to a wide range of environmental conditions (Sousa et al., 1995), and it is widely distributed in tropical and subtropical regions and in some temperate regions (Vaughan, 1994). Common bean is a leguminous species that presents a large number of varieties and cultivars spread over different continents, due to the high value of its seeds for human nutrition (Peixoto et al., 2000). Consumption of both can benefit human health due to the presence of antioxidant compounds (Walter and Marchesan, 2011; López et al., 2013).

Because of the importance of rice and beans as food items, large germplasm collections have been established, and there are studies reporting cytotoxic, mutagenic and/or

Send correspondence to Cesar Grisolia. Departamento de Genética e Morfologia, Instituto de Ciências Biológicas, Universidade de Brasília, Campus Darcy Ribeiro 7091-900 Brasília, DF, Brasil. E-mail: grisolia@unb.br. genotoxic evaluations in O. sativa (Mei et al., 1994; Todoriki and Toru, 1999; Mohanty et al., 2004; Wei et al., 2006; Shi et al., 2010; Endo et al., 2012; Kwon et al., 2013; Macovei and Tuteja, 2013; Macovei et al., 2014) and in $P$. vulgaris (Hallak et al., 1999; Khan et al., 2002, Cenkci et al., 2010). The use of methodologies to detect damage to DNA based on chromosome breaks and mis-segregation would play an important role in understanding genomic stability and the viability of seeds stored in gene banks, because the loss of genomic stability is one of the first stages in the seed deterioration process (Peixoto et al., 2006). In this case, methyl methanesulfonate (MMS) was used as reference compound for inducing such genomic damages in rice and beans. MMS is an alkylating agent capable of adding methyl groups to a series of nucleophilic sites in DNA bases (Wyatt and Pittman, 2006; Malini et al., 2010), which can cause chromosome aberrations (Kaina, 2004). It is used for mutagenic and genotoxic evaluation in different organisms, from fungi (Myung and Kolodner, 2003) to rodents (Muto et al., 2015; Plappert-Helbig et al., 2015).

The main goal of the present study was to test known cytogenetic methodologies and single cell gel electrophoresis (comet test), as tools for the measurement of genomic instability in seeds stored in a gene bank. 


\section{Material and Methods}

\section{Plant material}

Seeds from two accessions of $O$. sativa (BGA012099 "Ferrinho" and BGA008070 "Primavera") and from two accessions of $P$. vulgaris (GF004 and GF007) were obtained from the Active Germplasm Bank of Rice and Beans (Embrapa Rice and Beans, Santo Antônio de Goiás, GO, Brazil). They were stored for six months at $10{ }^{\circ} \mathrm{C}$ and $30 \%$ of humidity. Initial germination of the seeds was 97 and $94 \%$ for the accessions of O. sativa, BGA012099 "Ferrinho" and BGA008070 "Primavera", respectively, and 56 and $99 \%$ for the accessions of P. vulgaris, GF004 and GF007, respectively.

\section{Chemicals}

MMS (CAS N. 66-27-3), ethidium bromide, sodium dodecyl sulfate, tris (hydroxymethyl) methane, ethylene diamine tetraacetic acid (EDTA) and boric acid were acquired from Sigma-Aldrich (St. Louis, USA). Normal-melting-point (NMP) agarose was acquired from Life Technologies (New York, USA) and low-melting-point (LMP) agarose from Laboratorios Conda (Madrid, Spain).

\section{Cytogenetic tests}

Twenty seeds from two accessions of $O$. sativa $(2 n=$ $2 x=24)$ and 30 seeds from two accessions of $P$. vulgaris $(2 n=2 x=22)$ were imbibed in different concentrations of MMS for three periods of time: MMS $5 \mathrm{mg} / \mathrm{L}$ for 4,8 and $24 \mathrm{~h}$; MMS $10 \mathrm{mg} / \mathrm{L}$ for 4, 8 and $24 \mathrm{~h}$ and MMS $15 \mathrm{mg} / \mathrm{L}$ for 4, 8 and $24 \mathrm{~h}$. As well as these treatments, seeds from the different accessions were imbibed in only distilled water for 24 hours. As a control, seeds of $O$. sativa and $P$. vulgaris were used without exposure to MMS or distilled water. Next, the seeds from each treatment were sown in substrate of germitest paper, wetted with distilled water, at the proportion of $2.5 \mathrm{~mL} / \mathrm{g}$ of dry paper. The germitest papers with seeds remained at room temperature $\left(20-30{ }^{\circ} \mathrm{C}\right)$ until the roots reached between 1 and $2 \mathrm{~cm}$ for $O$. sativa, and between 1 and $3 \mathrm{~cm}$ for $P$. vulgaris. The roots were fixed in Carnoy solution (ethanol/glacial acetic acid - 3:1 v/v) and stored in ethanol $70 \%$ until slides were prepared.

The slides were prepared according to the methodology proposed by Guerra and de Souza (2002), with modifications. The roots were washed in distilled water for $5 \mathrm{~min}$, hydrolyzed in hydrochloric acid $(5 \mathrm{~N})$ for $25 \mathrm{~min}$, washed again in distilled water for $2 \mathrm{~min}$ and arranged on slides to cut the meristematic region of the roots and then to color with acetic orcein $2 \%$ for $15 \mathrm{~min}$. Next, the meristematic region was covered with a coverslip and evaluated under an optical microscope $(1,000 \mathrm{X})$.

Evaluation of 1,000 cells per root was carried out, with four roots per group, to a total of 4,000 cells analyzed per group tested. The parameters used to characterize the groups were: (a) Mitotic Index (MI) as an indication of cytotoxicity, (b) frequency of chromosome aberrations, and (c) frequency of micronuclei (MNs) as an indication of mutagenicity. For the analysis of chromosome alterations, we evaluated chromosome lagging and chromosome bridges in anaphase and/or telophase and chromosome fragments in metaphase, anaphase and/or telophase. The evaluation of the slides was carried out in a blind test.

\section{Comet test}

Ten seeds from the two accessions of $O$. sativa and from the two accessions of $P$. vulgaris were imbibed in different concentrations of MMS for a single period of time: MMS $5 \mathrm{mg} / \mathrm{L}$ for $24 \mathrm{~h}$; MMS $10 \mathrm{mg} / \mathrm{L}$ for $24 \mathrm{~h}$ and MMS 15 $\mathrm{mg} / \mathrm{L}$ for $24 \mathrm{~h}$. Similar to the cytogenetic tests, one group of seeds of $O$. sativa and $P$. vulgaris was also submitted to imbibition in distilled water for $24 \mathrm{~h}$. The control consisted of seeds of $O$. sativa and $P$. vulgaris without exposure to MMS or distilled water.

Cell suspensions were obtained from seed embryos from the two accessions of rice and bean for consequent processing in the test. Cell suspensions were obtained in accordance with Koppen and Cerda (1997), with some adaptations. The embryos collected were transferred to $2 \mathrm{~mL}$ microtubes containing $1 \mathrm{~mL}$ of cold phosphate buffered saline (PBS), macerated and left for $1 \mathrm{~h}$ in the refrigerator. Next, the supernatant was used to carry out the comet test.

The comet test was carried out in accordance with Cerda et al. (1997), with modifications. Fifteen microliters of the cell suspension were mixed with $85 \mu \mathrm{L}$ of LMP agarose $(0.8 \%)$ at $45^{\circ} \mathrm{C}$ and arranged on slides pre-covered with NMP agarose $(0.5 \%)$. Next, the slides were re-covered immediately with the coverslip, placed on a metal sheet, and put in the refrigerator for $5 \mathrm{~min}$. After the agarose gel solidified, the coverslips were removed and the slides immersed in TBE buffer solution (45 mM Tris-borate, $1 \mathrm{mM}$ EDTA, pH 8.4) containing 2.5\% sodium dodecyl sulfate for $30 \mathrm{~min}$. After the lysis phase, the slides were transferred to an electrophoresis tank containing TBE buffer solution and left to rest for $5 \mathrm{~min}$ before running electrophoresis at 0.5 $\mathrm{V} / \mathrm{cm}$ for $2 \mathrm{~min}$. To determine the most appropriate voltage for the observation of nucleoids of $O$. sativa and $P$. vulgaris embryos, SCGE tests were done with different voltages $(0.5,0.75,1$ and $2 \mathrm{~V} / \mathrm{cm}$ for rice and $0.5,0.75$ and $1 \mathrm{~V} / \mathrm{cm}$ for bean) for $2 \mathrm{~min}$. After electrophoresis, the slides were plunged into ice-cold distilled water for $10 \mathrm{~min}$, dried at room temperature and kept in the refrigerator until the moment for staining. The slides were stained with $50 \mu \mathrm{L}$ of ethidium bromide $(20 \mu \mathrm{g} / \mathrm{mL})$ and analyzed under a fluorescence microscope $(400 \mathrm{X})$ using excitation and emission filters of $546 \mathrm{~nm}$ and $590 \mathrm{~nm}$. All the steps took place in weak or yellow light. Three slides were prepared for each group of both species, and on the slides of $O$. sativa, between 20 and 50 nucleoids were analyzed per slide, due to the small quantity of nucleoids obtained in some slides; on the slides of $P$. vulgaris, 50 nucleoids were analyzed per 
slide. The evaluation of nucleoids of $O$. sativa and $P$. vulgaris embryos was done using the Comet Assay IV program, version 4.3.1, and the parameter of tail intensity was chosen to measure the damage to DNA as being indicative of genotoxicity. Slides were evaluated in a blind test.

\section{Statistical analysis}

The statistical analyses of the data from the cytogenetic and comet tests were done with GraphPad Prism software, version 5.00, using One-way ANOVA followed by the Tukey test with significance levels of $p<0.05$.

\section{Results and Discussion}

Initially, seeds of $O$. sativa and $P$. vulgaris were exposed only to distilled water for $24 \mathrm{~h}$ to verify the influence of imbibition, as the excess of water could be damaging for the seeds and interfere indirectly in the oxygenation of the embryo (Black et al., 2006). However, it was observed that imbibition of the seeds in water for $24 \mathrm{~h}$ did not induce observable damage $(p \geq 0.05)$ in the cytogenetic and comet tests in seeds from the two accessions of $O$. sativa and $P$. vulgaris that were evaluated.

\section{Cytogenetic tests}

In the $O$. sativa accessions evaluated, MMS significantly inhibited the MI of meristematic cells of the roots of accession BGA012099 "Ferrinho" at the concentration of $15 \mathrm{mg} / \mathrm{L}$ for 4 and $8 \mathrm{~h}$, when compared with the control (Table 1). In addition, MMS significantly reduced the MI of meristematic root cells of accession BGA008070 "Primavera" at the concentration of $15 \mathrm{mg} / \mathrm{L}$ for $4 \mathrm{~h}$, when compared with the control (Table 2). In accession GF004 of P. vulgaris, MMS at the concentration of 10 and $15 \mathrm{mg} / \mathrm{L}$ for $24 \mathrm{~h}$ reduced the MI of the meristematic root cells of accession GF004, differing statistically from the other groups tested (Table 3). This indicated that exposure time may be a determining factor for the observation of these effects. In accession GF007, MMS significantly reduced the MI of the meristematic root cells at the concentration of $15 \mathrm{mg} / \mathrm{L}$ for $24 \mathrm{~h}$, when compared to the control and to distilled water (Table 4).

In mammals, MMS induces a collapse in the replication forks or a halt in replication due to the addition of methyl groups to the DNA molecule, preventing the progression of DNA replication in the cell cycle (Wyatt and Pittman, 2006). Although cytotoxic damages of MMS have not been previously reported in the literature with the plants evaluated in the present study, the cytotoxicity of MMS has been reported in meristematic cells of plant roots, such as Allium cepa L. (Rank and Nielsen, 1993), and it is well established as a positive control in A. cepa test (Liman et al., 2015).

A series of events occur in the seed up until its complete germination. Seed metabolism begins after hydration. Respiration and synthesis of proteins begin minutes after hydration, followed by RNA synthesis, repair mechanisms and DNA synthesis. The last event in germination is the expansion of the cells in the radicle, preceding cell division. Most seeds do not manage to germinate when immersed in

Table 1 - Mitotic index, frequency of chromosome aberrations and of micronuclei obtained in the cytogenetic tests on cells from the meristematic region ( $\mathrm{n}=4000)$ in roots of Oryza sativa L. accession BGA012099 "Ferrinho", exposed to methyl methanesulfonate (MMS).

\begin{tabular}{|c|c|c|c|c|c|c|}
\hline \multirow[t]{2}{*}{ Groups } & \multirow[t]{2}{*}{ Mitotic Index } & \multicolumn{3}{|c|}{ Chromosome aberrations } & \multirow[b]{2}{*}{ Total frequency } & \multirow{2}{*}{$\begin{array}{l}\text { Micronuclei } \\
\text { frequency }\end{array}$} \\
\hline & & Chromosome lagging & Fragments & Bridges & & \\
\hline Control & $8.42 \pm 0.91$ & $0.25 \pm 0.50$ & - & - & $0.25 \pm 0.50$ & - \\
\hline Distilled water & $6.82 \pm 0.68$ & $1.00 \pm 0.81$ & $0.25 \pm 0.50$ & - & $1.25 \pm 0.50$ & - \\
\hline \multicolumn{7}{|l|}{ MMS 5 mg/L } \\
\hline $4 \mathrm{~h}$ & $7.42 \pm 1.47$ & $0.25 \pm 0.50$ & - & - & $0.25 \pm 0.50$ & - \\
\hline $8 \mathrm{~h}$ & $8.35 \pm 0.42$ & $1.00 \pm 0.81$ & - & - & $1.00 \pm 0.81$ & - \\
\hline $24 \mathrm{~h}$ & $7.77 \pm 1.07$ & $0.75 \pm 0.95$ & - & $0.50 \pm 0.74$ & $1.25 \pm 0.95$ & - \\
\hline \multicolumn{7}{|l|}{ MMS $10 \mathrm{mg} / \mathrm{L}$} \\
\hline $4 \mathrm{~h}$ & $7.67 \pm 1.17$ & $1.75 \pm 0.95$ & $0.75 \pm 0.95$ & - & $2.50 \pm 1.00$ & $0.25 \pm 0.50$ \\
\hline $8 \mathrm{~h}$ & $7.40 \pm 0.60$ & $1.25 \pm 0.95$ & $0.75 \pm 0.50$ & $0.75 \pm 0.95$ & $2.50 \pm 1.29$ & $0.25 \pm 0.50$ \\
\hline $24 \mathrm{~h}$ & $8.40 \pm 0.49$ & $1.75 \pm 1.70$ & $0.25 \pm 0.50$ & $0.75 \pm 1.50$ & $2.75 \pm 1.50^{\mathrm{a}^{*}}$ & - \\
\hline \multicolumn{7}{|l|}{ MMS 15 mg/L } \\
\hline $4 \mathrm{~h}$ & $6.27 \pm 0.76^{\mathrm{a}^{*}}$ & $0.75 \pm 1.50$ & $0.50 \pm 0.57$ & - & $1.25 \pm 1.25$ & - \\
\hline $8 \mathrm{~h}$ & $6.02 \pm 0.91^{\mathrm{a}^{* *}}$ & - & $0.25 \pm 0.50$ & $0.50 \pm 1.00$ & $0.75 \pm 0.95$ & - \\
\hline $24 \mathrm{~h}$ & $6.95 \pm 0.62$ & $1.50 \pm 1.73$ & - & - & $1.50 \pm 1.73$ & - \\
\hline
\end{tabular}

Control = seeds not exposed to MMS (methyl methanesulfonate) or to distilled water. $(-)=$ not observed. The data are represented as means \pm SD; ${ }^{a}$ significant in relation to control; One-way ANOVA followed by Tukey test. $\left({ }^{*} p<0.05 ;{ }^{* *} p<0.01\right)$. 
water, but the seeds of some aquatic plants, such as rice, do manage to germinate successfully in this condition (Black et al., 2006). This characteristic of rice may help to explain the fact that no cytotoxic effects were observed occasioned by MMS in accessions of $O$. sativa in the period of $24 \mathrm{~h}$ for accession BGA012099 "Ferrinho", and in the periods of 8 and $24 \mathrm{~h}$ for accession BGA008070 "Primavera". The absorption of MMS in the first periods of exposure of these accessions of $O$. sativa may delay the events that occur until germination, especially the repair and synthesis of DNA, which would be continued later. This is corroborated by the absence of cytotoxic effects in the longer exposure periods.

It should be noted that for seeds of accession GF004 of bean, lower MI values were already observed in intermediate concentrations of MMS, differently from rice. At the highest concentration, of $15 \mathrm{mg} / \mathrm{L}$, the period of $8 \mathrm{~h}$ was sufficient to reduce the MI, when compared to the MMS 15 $\mathrm{mg} / \mathrm{L}$ group for $4 \mathrm{~h}$. It may be suggested that for bean seeds the process of DNA synthesis and repair may occur in the initial stages of imbibition. Comparing the two bean accessions, the initial germination of the seeds of GF007 was $99 \%$, well above that of GF004, which was 56\%. This may have had an influence on the greater sensitivity of the seeds of accession GF004 to the deleterious effects of MMS.

Mutagenicity can also be analyzed by cytogenetic tests in meristematic cells of plant roots by using the frequencies of chromosome aberrations and MNs (Leme and Marin-Morales, 2009). MMS occasioned mutagenic effects by the significant increase in the frequency of chromosome aberrations in meristematic cells of $O$. sativa roots at the concentration of $10 \mathrm{mg} / \mathrm{L}$ when exposed for $24 \mathrm{~h}$ in accession BGA012099 "Ferrinho" (Table 1) and for 8 and $24 \mathrm{~h}$ in accession BGA008070 "Primavera" (Table 2), when compared with the control. In the latter accession, there was a significant increase in chromosome fragments for an exposure period of $24 \mathrm{~h}$ in relation to the control group and distilled water. The significant increase in chromosome fragments induced by MMS in meristematic cells of $O$. sativa roots corroborated what has been reported on the clastogenic action of MMS (Kaina, 2004). The capacity of MMS to produce breaks seems to depend largely on generating intermediaries of base excision repair (BER), since studies suggest that the intermediaries of BER generated by the removal of N-methylpurines are toxic and clastogenic (Wyatt and Pittman, 2006).

In accession GF004 of $P$. vulgaris, MMS at the concentration of $10 \mathrm{mg} / \mathrm{L}$ for $8 \mathrm{~h}$ induced an increase in the occurrence of chromosome lagging in meristematic root cells of accession GF004, which differed statistically from the control, from the distilled water, and from the MMS 10 $\mathrm{mg} / \mathrm{L}$ for $4 \mathrm{~h}$ group. There was also an increase in the total frequency of chromosome aberrations in the meristematic root cells for the MMS $10 \mathrm{mg} / \mathrm{L}$ for $8 \mathrm{~h}$ group, when compared with the control and distilled water. Similar effects were found for MMS at the concentration of $15 \mathrm{mg} / \mathrm{L}$. In other words, there was an increase in the presence of chromosome lagging and total frequency of chromosome aberrations after exposure for $4 \mathrm{~h}$ in relation to all the groups tested (Table 3). The fact that no significant increase in chromosome lagging and chromosome aberrations was

Table 2 - Mitotic index, frequency of chromosome aberrations and of micronuclei obtained in the cytogenetic tests on cells from the meristematic region $(\mathrm{n}=4000)$ in roots of Oryza sativa L. accession BGA008070 "Primavera" exposed to methyl methanesulfonate (MMS).

\begin{tabular}{|c|c|c|c|c|c|c|}
\hline \multirow[t]{2}{*}{ Groups } & \multirow[t]{2}{*}{ Mitotic Index } & \multicolumn{3}{|c|}{ Chromosome aberrations } & \multirow[b]{2}{*}{ Total frequency } & \multirow{2}{*}{$\begin{array}{l}\text { Micronuclei } \\
\text { frequency }\end{array}$} \\
\hline & & Chromosome lagging & Fragments & Bridges & & \\
\hline Control & $8.05 \pm 1.30$ & - & - & - & - & - \\
\hline Distilled water & $6.77 \pm 0.49$ & $0.50 \pm 0.74$ & - & - & $0.50 \pm 0.74$ & - \\
\hline \multicolumn{7}{|l|}{ MMS 5 mg/L } \\
\hline $4 \mathrm{~h}$ & $7.42 \pm 1.47$ & $0.50 \pm 0.74$ & - & - & $0.50 \pm 0.74$ & - \\
\hline $8 \mathrm{~h}$ & $8.35 \pm 0.42$ & $0.50 \pm 1.00$ & $0.50 \pm 0.74$ & $0.50 \pm 1.00$ & $1.50 \pm 1.73$ & - \\
\hline $24 \mathrm{~h}$ & $7.77 \pm 1.07$ & - & $0.50 \pm 0.74$ & - & $0.50 \pm 0.74$ & - \\
\hline \multicolumn{7}{|l|}{ MMS 10 mg/L } \\
\hline $4 \mathrm{~h}$ & $7.40 \pm 0.77$ & $0.50 \pm 1.00$ & $1.25 \pm 1.50$ & - & $1.75 \pm 1.25$ & $0.25 \pm 0.50$ \\
\hline $8 \mathrm{~h}$ & $7.50 \pm 0.50$ & $1.00 \pm 0.81$ & $1.25 \pm 0.95$ & $0.50 \pm 1.00$ & $2.75 \pm 1.50^{\mathrm{a}^{*}}$ & $0.50 \pm 0.57$ \\
\hline $24 \mathrm{~h}$ & $7.17 \pm 2.14$ & $0.75 \pm 1.50$ & $2.25 \pm 1.25^{\mathrm{a}^{*} ; \mathrm{b}^{*}}$ & - & $3.00 \pm 1.15^{\mathrm{a}^{* *} ; \mathrm{b}^{*}}$ & - \\
\hline \multicolumn{7}{|l|}{ MMS 15 mg/L } \\
\hline $4 \mathrm{~h}$ & $5.77 \pm 0.85^{\mathrm{a}^{*}}$ & $0.75 \pm 1.50$ & $0.50 \pm 0.57$ & $0.25 \pm 0.50$ & $1.50 \pm 2.38$ & - \\
\hline $8 \mathrm{~h}$ & $7.00 \pm 0.98$ & $0.25 \pm 0.50$ & $0.25 \pm 0.50$ & - & $0.50 \pm 0.57$ & - \\
\hline $24 \mathrm{~h}$ & $7.85 \pm 1.05$ & $0.75 \pm 0.95$ & $0.75 \pm 0.50$ & - & $1.50 \pm 1.29$ & - \\
\hline
\end{tabular}

Control $=$ seeds not exposed to MMS (methyl methanesulfonate) or to distilled water. (-) = not observed. The data are represented as means \pm SD; ${ }^{a}$ significant in relation to control; ${ }^{b}$ significant in relation to the distilled water group; One-way ANOVA followed by Tukey test. $\left({ }^{*} p<0.05 ;{ }^{* *} p<0.01\right)$. 
Table 3 - Mitotic index, frequency of chromosome aberrations and of micronuclei obtained in the cytogenetic tests on cells from the meristematic region $(\mathrm{n}=4000)$ in roots of Phaseolus vulgaris L. accession GF004, exposed to methyl methanesulfonate (MMS).

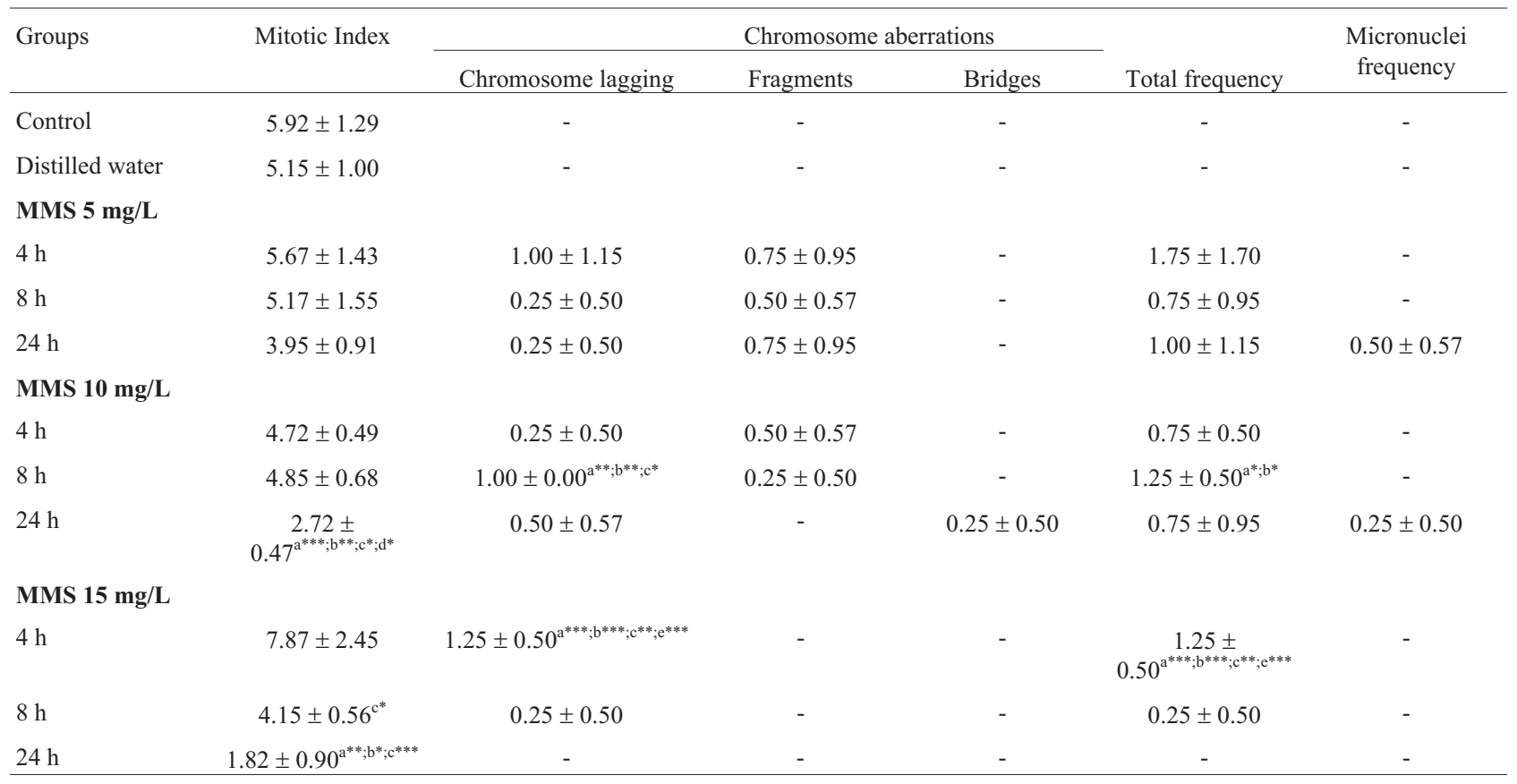

Control $=$ seeds not exposed to MMS (methyl methanesulfonate) or to distilled water. (-) = not observed. The data are represented as means \pm SD; ${ }^{a}$ significant in relation to control; ${ }^{\mathrm{b}}$ significant in relation to the distilled water group; ${ }^{\mathrm{c}}$ significant in relation to the time of $4 \mathrm{~h} ;{ }^{\mathrm{d}}$ significant in relation to the time of $8 \mathrm{~h} ;{ }^{\mathrm{e}}$ significant in relation to the time of $24 \mathrm{~h}$. One-way ANOVA followed by Tukey test. $\left({ }^{*} p<0.05 ;{ }^{* *} p<0.01 ;{ }^{* * * *} p<0.001\right)$.

seen in periods later than those observed, at concentrations of 10 and $15 \mathrm{mg} / \mathrm{L}$ in accession GF004 of bean ( $\mathrm{p} \geq 0.05)$, may be explained as being due to mitotic inhibition for an exposure period of $24 \mathrm{~h}$, because the chromosome aberrations evaluated in this study require cells that are undergoing division to be noticed (Rank, 2003). MMS is a clastogenic agent, and thus promotes chromosome breaks and the induction of chromosome lagging in plants, as previously reported in Capsicum annum L. (Gulfishan et al., 2011; 2012) and Vicia faba L. (Sharma et al., 2009) and also observed in the present study. In accession GF007, MMS did not produce a significant increase in the frequency of chromosome aberrations in the meristematic root cells, when compared with the control (Table 4).

Despite the significant increase in the frequency of chromosome aberrations in accessions BGA012099 "Ferrinho" and BGA008070 "Primavera" of $O$. sativa and in GF004 of $P$. vulgaris, MMS did not induce a significant increase in $\mathrm{MN}$ frequency in the meristematic root cells in the two tested accessions of $O$. sativa and $P$. vulgaris, when compared with the control. Furthermore, all MNs found were very small, suggesting that these came from a clastogenic effect. Chromosome aberrations are the main mechanisms in $\mathrm{MN}$ formation, but they may not produce MNs in daughter cells, because chromosome lagging, chromosome bridges and chromosome fragments originating from bridges can be corrected, or have their effects minimized (Rao et al., 2008).

\section{Comet test}

Before carrying out the comet test, different voltages were checked for the electrophoresis stage. This was carried out with the purpose of determining which voltage was most appropriate for observing embryo nucleoids of $O$. sativa and of $P$. vulgaris. As described in the literature, in the control the percentage of DNA found in the tail of nucleoids should be between 10 and $20 \%$ to avoid false positive results and statistical errors (Lovell and Omori, 2008). Only the voltage of $0.5 \mathrm{~V} / \mathrm{cm}$ showed results between 10 and $20 \%$, and it was thus the most appropriate voltage (Figure 1). It should be emphasized that the neutral version of the test was used, in which the nucleoids of cells untreated with a genotoxic agent possess more DNA in the tail region of the comet when compared to nucleoids in the alkaline version of the test (Olive and Banáth, 2006). Therefore, the values of mean intensity from the nucleoid tails in the control experiment for the two $O$. sativa accessions were close to the maximal limit established, which is $20 \%$.

The results of the comet tests are represented in Figures 2 and 3. MMS led to a significant increase in the tail intensity in the embryo nucleoids of the two accessions of $O$. sativa evaluated at all the tested concentrations, when compared to the control (Figure 2). In the rice accession BGA012099 "Ferrinho", MMS at the concentration of 15 $\mathrm{mg} / \mathrm{L}$ also differed statistically from the distilled water group (Figure 2A) and in rice accession BGA008070 
Table 4 - Mitotic index, frequency of chromosome aberrations and of micronuclei obtained in the cytogenetic tests on cells from the meristematic region $(\mathrm{n}=4000)$ in roots of Phaseolus vulgaris L. accession GF007, exposed to methyl methanesulfonate (MMS).

\begin{tabular}{|c|c|c|c|c|c|c|}
\hline \multirow[t]{2}{*}{ Groups } & \multirow[t]{2}{*}{ Mitotic Index } & \multicolumn{4}{|c|}{ Chromosome aberrations } & \multirow{2}{*}{$\begin{array}{l}\text { Micronuclei } \\
\text { frequency }\end{array}$} \\
\hline & & Chromosome lagging & Fragments & Bridges & Total frequency & \\
\hline Control & $7.90 \pm 1.60$ & - & - & - & - & - \\
\hline Distilled water & $5.97 \pm 1.21$ & $0.25 \pm 0.50$ & - & - & $0.25 \pm 0.50$ & - \\
\hline \multicolumn{7}{|l|}{ MMS 5 mg/L } \\
\hline $4 \mathrm{~h}$ & $8.00 \pm 1.60$ & $0.25 \pm 0.50$ & - & $0.25 \pm 0.50$ & $0.50 \pm 0.57$ & $0.25 \pm 0.50$ \\
\hline $8 \mathrm{~h}$ & $5.47 \pm 2.10$ & $0.25 \pm 0.50$ & $0.25 \pm 0.50$ & - & $0.50 \pm 1.00$ & - \\
\hline $24 \mathrm{~h}$ & $6.37 \pm 2.65$ & $0.25 \pm 0.50$ & - & - & $0.25 \pm 0.50$ & - \\
\hline \multicolumn{7}{|l|}{ MMS 10 mg/L } \\
\hline $4 \mathrm{~h}$ & $8.15 \pm 3.37$ & - & - & $0.25 \pm 0.50$ & $0.25 \pm 0.50$ & - \\
\hline $8 \mathrm{~h}$ & $6.67 \pm 1.21$ & $0.25 \pm 0.50$ & - & $0.25 \pm 0.50$ & - & - \\
\hline $24 \mathrm{~h}$ & $5.17 \pm 1.42$ & $1.50 \pm 1.73$ & $0.25 \pm 0.50$ & - & $1.75 \pm 1.70$ & - \\
\hline \multicolumn{7}{|l|}{ MMS 15 mg/L } \\
\hline $4 \mathrm{~h}$ & $8.35 \pm 1.27$ & $0.50 \pm 1.00$ & $0.25 \pm 0.50$ & $0.25 \pm 0.50$ & $1.00 \pm 1.41$ & - \\
\hline $8 \mathrm{~h}$ & $7.07 \pm 1.87$ & $0.50 \pm 0.57$ & - & $0.75 \pm 1.50$ & $1.25 \pm 1.89$ & - \\
\hline $24 \mathrm{~h}$ & $4.52 \pm 0.95^{\mathrm{a}^{*} ; \mathrm{b}^{*}}$ & $1.25 \pm 1.25$ & $0.25 \pm 0.50$ & - & $1.50 \pm 1.29$ & - \\
\hline
\end{tabular}

Control = seeds not exposed to MMS (methyl methanesulfonate) or to distilled water. $(-)=$ not observed. The data are represented as means \pm SD; ${ }^{a}$ significant in relation to the control; ${ }^{\mathrm{b}}$ significant in relation to the distilled water group. One-way ANOVA followed by Tukey test. $\left({ }^{*} p<0.05\right)$.

"Primavera" the MMS concentrations that differed statistically from the distilled water group were 5 and $10 \mathrm{mg} / \mathrm{L}$ (Figure 2B).

In the accessions of $P$. vulgaris, MMS also produced a significant increase in tail intensity of embryo nucleoids at all the tested concentrations (Figure 3), except at the concentration of $5 \mathrm{mg} / \mathrm{L}$ in the accession GF004 of $P$. vulgaris (Figure 3A). In bean accession GF004, there was an increase in nucleoid tail intensity in the concentrations of 10 and $15 \mathrm{mg} / \mathrm{L}$ of MMS, when compared to the distilled water group; the concentration of $15 \mathrm{mg} / \mathrm{L}$ also differed statistically from the group exposed to MMS at the concentration of $5 \mathrm{mg} / \mathrm{L}$, indicating a possible relationship between the concentration of MMS and the genotoxic effects observed in the comet test. In bean accession GF007, only the concentration of $15 \mathrm{mg} / \mathrm{L}$ of MMS differed statistically from the distilled water group (Figure 3B). The profiles of nucleoids obtained in our laboratory for rice and common bean are shown in Figure 4. MMS, when used as positive control to evaluate two auxinic herbicides, at a concentra-
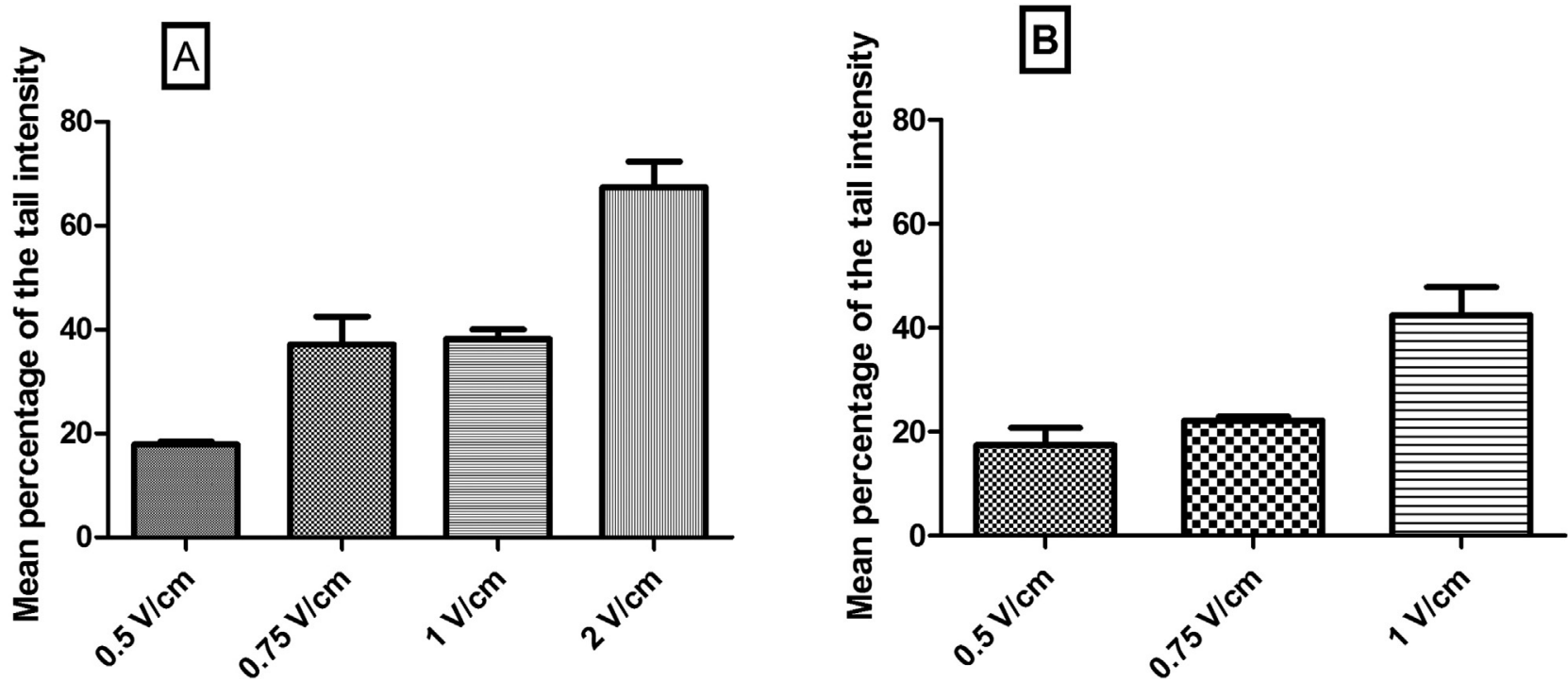

Figure 1 - Mean percentage of tail intensity of nucleoids submitted to different voltages in the electrophoresis test in single cell gel. A) Embryo nucleoids from $O$. sativa seeds. B) Embryo nucleoids of $P$. vulgaris seeds. The data are represented as means \pm SEM. 

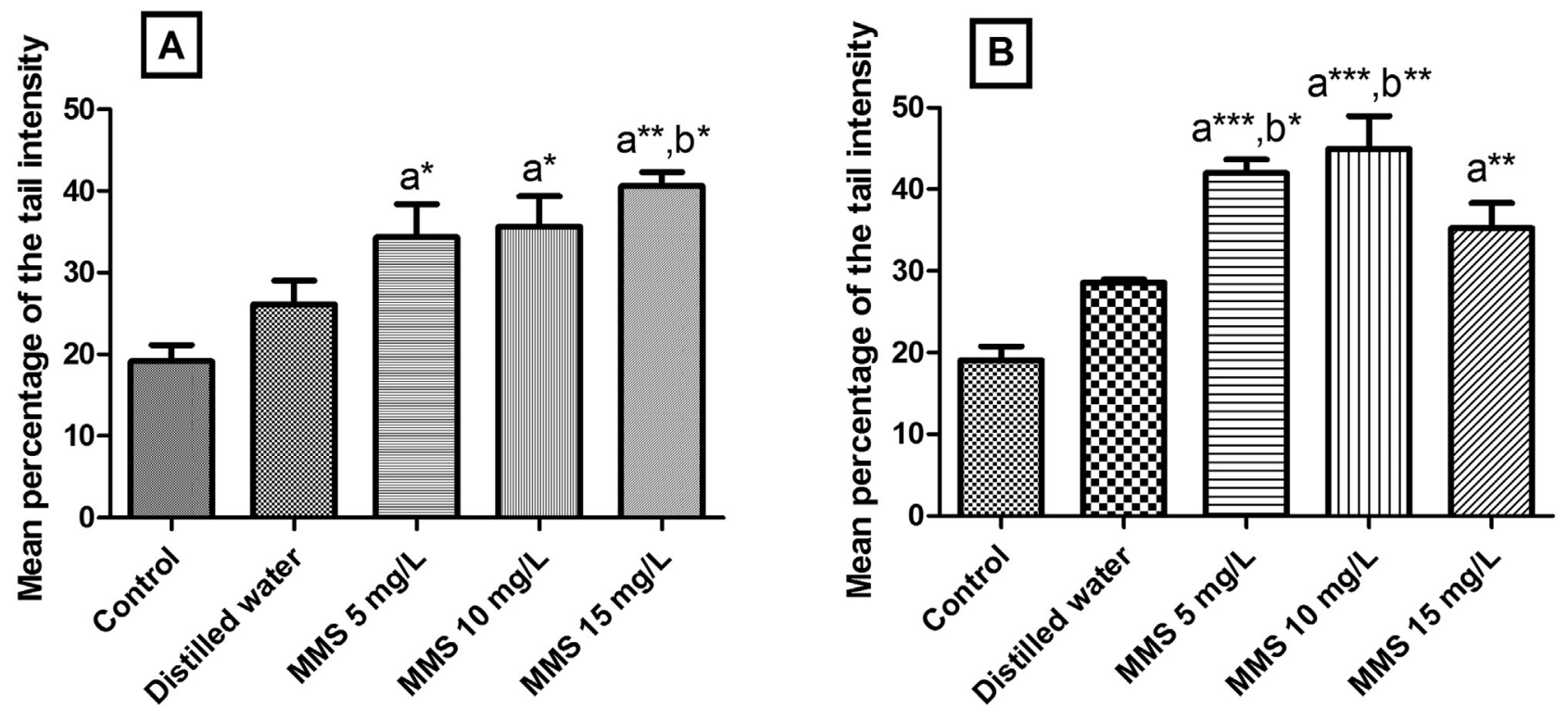

Figure 2 - Mean percentage of tail intensity of nucleoids from Oryza sativa L. exposed to different concentrations of methyl methanesulfonate (MMS). A) accession BGA012099 "Ferrinho". B) accession BGA008070 "Primavera". The data are represented as means \pm SEM. Control = seeds not exposed to MMS or to distilled water. ${ }^{\mathrm{a}}$ Significant in relation to control. ${ }^{\mathrm{b}}$ Significant in relation to distilled water group. One-way ANOVA followed by Tukey test $(* p<0.05 ; * * p<0.01 ; * * * p<0.001)$.
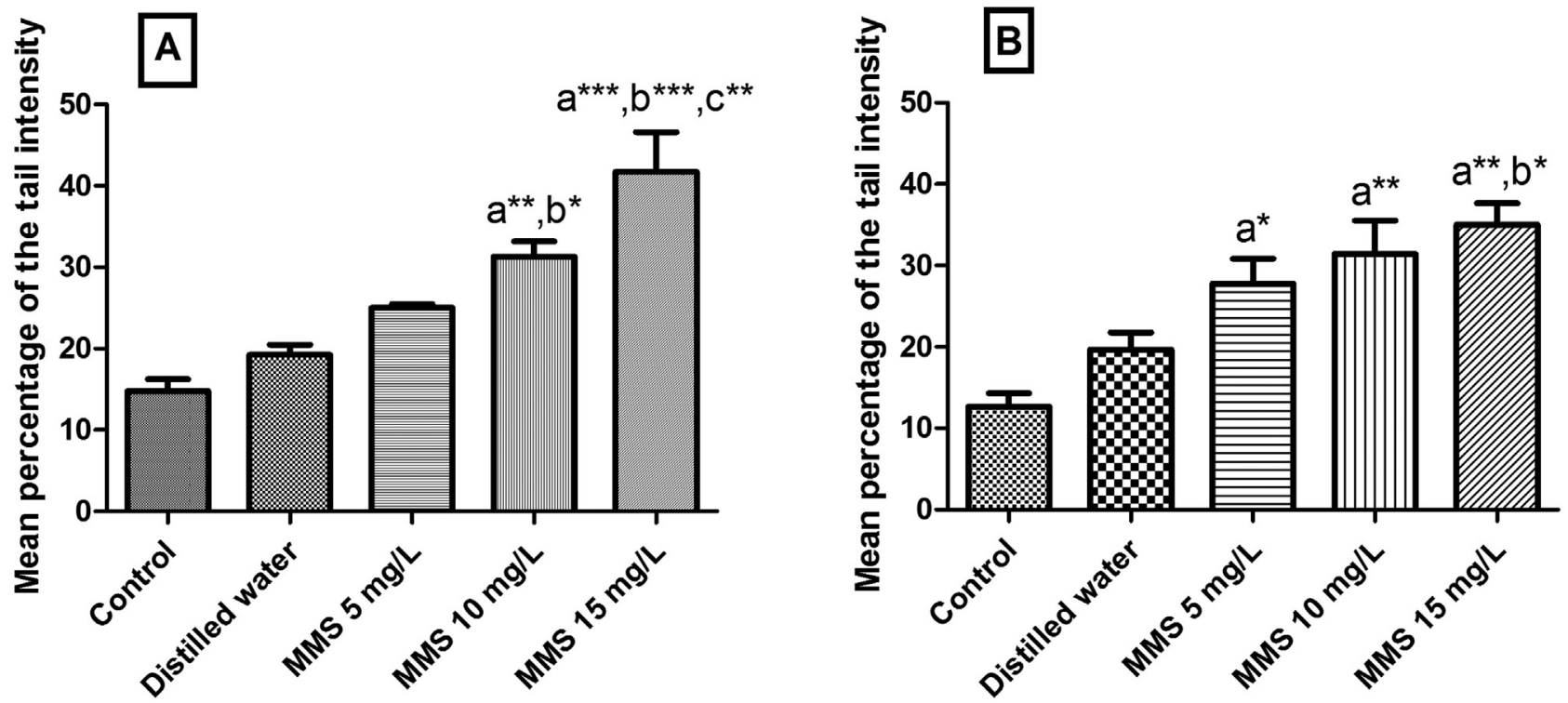

Figure 3 - Mean percentage of tail intensity of nucleoids from Phaseolus vulgaris L. exposed to different concentrations of methyl methanesulfonate (MMS). A) accession GF004. B) accession GF007. The data are represented as means \pm SEM. Control $=$ seeds not exposed to MMS or to distilled water. ${ }^{a}$ Significant in relation to control. ${ }^{\mathrm{b}}$ Significant in relation to distilled water group. ${ }^{\mathrm{c}}$ Significant in relation to MMS $5 \mathrm{mg} / \mathrm{L}$ group. One-way ANOVA followed by Tukey test $\left({ }^{*} p<0.05 ; * * p<0.01 ; * * * p<0.001\right)$.

tion of $10 \mathrm{ppm}$, demonstrated high genotoxic activity in a mild alkaline comet test ( $\mathrm{pH} 12.3)$ in roots of $P$. vulgaris (Cenkci et al., 2010).

The neutral version of the comet test can detect breaks in single and double strands (Collins et al., 2008). Breaks in single strands seen during cell treatment with MMS are probable intermediaries of BER, while breaks in double strands are the result of replication forks that en- counter methyl damage or strand breakage produced by intermediaries of BER (Wyatt and Pittman, 2006). However, damage observed during the comet test can be repaired by cell repair mechanisms (Villela et al., 2003). Therefore, the genotoxic damage occasioned by MMS in the two evaluated accessions of $O$. sativa and $P$. vulgaris may be reparable. 

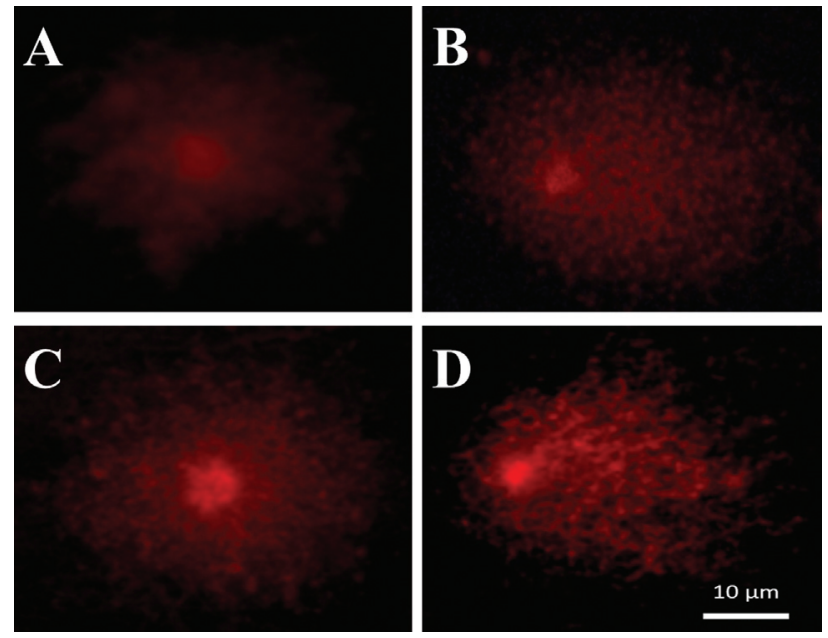

Figure 4 - Profiles of nucleoids observed in the comet assay in rice and common beans. A and $\mathbf{C}$ ) Nucleoids of $O$. sativa and $P$. vulgaris control embryos, respectively. B and D) nucleoids of $O$. sativa and $P$. vulgaris embryos exposed to MMS, respectively.

The comet test is a very sensitive bioassay that evaluates damage to DNA, and this sensitivity may have contributed to detecting the damage occasioned by MMS at concentrations that did not produce significant effects in the cytogenetic tests. In addition, this test was carried out soon after exposing rice and bean seeds to MMS, but the seeds needed to have germinated for the cytogenetic tests after exposure to MMS. Germination and growth took 2 to 5 days for roots to be obtained at the ideal size for cytogenetic tests. This period may have been sufficient to repair damage to DNA (Villela et al., 2003). It is worth highlighting the value of cytogenetic tests together with the comet test, as together they provide a better understanding of the results obtained, because damage such as MN formation, is irreversible in cells, whereas damage seen in the comet test can be repaired (Vasquez, 2010).

\section{Conclusion}

Rice and beans showed sensitivity to the cytotoxic, mutagenic and genotoxic effects of MMS. This study provides contributions to the standardization of methodologies to evaluate cytotoxicity, mutagenicity and genotoxicity in rice and beans. It was shown that the comet test is more sensitive than the cytogenetic tests used. The comet test, in particular, can be proposed for the measurement of genomic instability in accessions of rice and beans in gene banks. This may contribute to establishing sensitive tools to detect deterioration caused by accelerated aging and storage conditions in gene banks.

\section{Acknowledgments}

This project was supported by Embrapa Genetic Resources \& Biotechnology, the Coordination for Training Higher Level Staff (CAPES), the National Council for Sci- entific and Technological Development (CNPq) and the University of Brasília.

\section{References}

Barbosa L (2007) Feijão com arroz e arroz com feijão: O Brasil no prato dos brasileiros. Horiz Antropol 28:87-116.

Black M, Bewley JD and Halmer P (2006) The Encyclopedia of Seeds: Science, Technology and Uses. CABI, Wallingford, $900 \mathrm{pp}$.

Cenkci S, Yildiz M, Cigerci IH, Bozdag A, Terzi H and Terzi ESA (2010) Evaluation of 2,4-D and Dicamba genotoxicity in bean seedlings using comet and RAPD assays. Ecotoxicol Environ Saf 73:1558-1564.

Cerda H, Delincée H, Haine H and Rupp H (1997) The DNA 'comet assay' as a rapid screening technique to control irradiated food. Mutat Res 375:167-181.

Collins AR, Oscoz AA, Brunborg G, Gaivão I, Giovannelli L, Kruszewski M, Smith CC and Stetina R (2008) The comet assay: Topical issues. Mutagenesis 23:143-151.

Endo M, Nakayama S, Umeda-Hara C, Ohtsuki N, Saika H, Umeda M and Toki S (2012) CDKB2 is involved in mitosis and DNA damage response in rice. Plant J 69:967-977.

Guerra M and de Souza MJ (2002) Como Observar Cromossomos: Um Guia de Técnicas em Citogenética Vegetal, Animal e Humana. FUNPEC, Riberão Preto, 131 pp.

Gulfishan M, Khan AH and Jafri IF (2011) Genotoxic effects induced by methyl methane sulphonate in 2 cultivars of Capsicum annuum L. Cytologia 76:381-385.

Gulfishan M, Khan AH, Jafri IF and Bhat TA (2012) Assessment of mutagenicity induced by MMS and DES in Capsicum annuum L. Saudi J Biol Sci 19:251-255.

Hallak AMG, Davide LC and Souza IF (1999) Effects of sorghum (Sorghum bicolor L.) root exudates on the cell cycle of the bean plant (Phaseolus vulgaris L.) root. Genet Mol Biol 22:95-99.

Kaina B (2004) Mechanisms and consequences of methylating agent-induced SCEs and chromosomal aberrations: A long road traveled and still a far way to go. Cytogenet. Genome Res 104:77-86.

Khan AA, Khan HM and Delincée H (2002) Detection of radiation treatment of beans using DNA comet assay. Radiat Phys Chem 63:407-410.

Koppen G and Cerda H (1997) Identification of low-dose irradiated seeds using the neutral comet assay. Lebensm Wiss Technol 30:452-457.

Kwon YI, Abe K, Endo M, Osakabe K, Ohtsuki N, Nishizawa-Yokoi A, Tagiri A, Saika H and Toki S (2013) DNA replication arrest leads to enhanced homologous recombination and cell death in meristems of rice OsRecQ14 mutants. BMC Plant Biol 13:62.

Leme DM and Marin-Morales MA (2009) Allium cepa test in environmental monitoring: A review on its application. Mutat Res 682:71-81.

Liman R, Cigerci IH and Öztürk NS (2015) Determination of genotoxic effects of Imazethapyr herbicide in Allium cepa root cells by mitotic activity, chromosome aberration, and comet assay. Pest Biochem Physiol 118:38-42.

López A, El-Naggar T, Dueñas M, Ortega T, Estrella I, Hernández T, Gómez-Serranillos MP, Palomino OM and Carretero ME (2013) Effect of cooking and germination on phenolic com- 
position and biological properties of dark beans (Phaseolus vulgaris L.). Food Chem 138:547-555.

Lovell DP and Omori T (2008) Statistical issues in the use of the comet assay. Mutagenesis. 23:171-182.

Macovei A and Tuteja N (2013) Different expression of miRNAs targeting helicases in rice in response to low and high dose rate $\gamma$-ray treatments. Plant Signal Behav 8:1-11.

Macovei A, Garg B, Raikwar S, Balestrazzi A, Carbonera D, Buttafava A, Bremont JFJ, Gill SS and Tuteja N (2014) Synergistic exposure of rice seeds to different doses of $\gamma$-ray and salinity stress resulted in increased antioxidant enzyme activities and gene-specific modulation of TC-NER pathway. Biomed Res Int 2014:676934.

Malini M, Marin-Morales MA, Mantovani MS, Jamal CM, Nati N, Passos T da S and Matsumoto ST (2010) Determination of the antimutagenicity of an aqueous extract of Rhizophora mangle L. (Rhizophoraceae), using in vivo and in vitro test systems. Genet Mol Biol 33:176-181.

Mei M, Deng H, Lu Y, Zhaung C, Liu Z, Qiu Q, Qui Y and Yang TC (1994) Mutagenic effects of heavy ion radianton in plants. Adv Space Res 14:363-372.

Mohanty S, Das AB, Das P and Mohanty P (2004) Effect of a low dose of aluminum on mitotic and meiotic activity, 4C DNA content, and pollen sterility in rice, Oryza sativa L. cv. Lalat. Ecotoxicol Environ Saf 59:70-75.

Muto S, Yamada K, Kato T, Wako Y, Kawasako K, Iwase Y and Uno Y (2015) Assessment of methyl methanesulfonate using the repeated-dose liver micronucleus assay in young adult rats. Mutat Res 780-781:107-110.

Myung K and Kolodner RD (2003) Induction of genome instability by DNA damage in Saccharomyces cerevisiae. DNA Repair 2:243-258.

Olive PL and Banáth JP (2006) The Comet assay: A method to measure DNA damage in individual cells. Nat Protoc $1: 23-29$.

Peixoto AM, de Toledo FF, Reichardt K, Filho Molina J and de Sousa JSI (2000) Enciclopédia Agrícola Brasileira: E-H. Editora da Universidade de São Paulo, São Paulo, 511 p.

Peixoto AM, de Sousa JSI, de Toledo FF, Reichardt K and Filho JM (2006) Enciclopédia Agrícola Brasileira: S-Z, 6th volume. Editora da Universidade de São Paulo, São Paulo, 632 p.

Plappert-Helbig U, Junker-Walker U and Martus HJ (2015) Evaluation of methyl methanesulfonate, 2,6-diaminotoluene and 5-fluorouracil: Part of the Japanese center for the validation of alternative methods (JaCVAM) international validation study of the in vivo rat alkaline comet assay. Mutat Res 786-788:120-124.
Rank J (2003) The method Allium anaphase-telophase chromosome aberration assay. Ekologija 1:38-42.

Rank J and Nielsen MH (1993) A modified Allium test as a tool in the screening of the genotoxicity of complex mixtures. Hereditas 118:49-53.

Rao X, Zhang Y, Yia Q, Hou H, Xu B, Chu L, Huang Y, Zhang W, Fenech M and Shi Q (2008) Multiple origins of spontaneously arising micronuclei in HeLa cells: Direct evidence from long-term live cell imaging. Mutat Res 646:41-49.

Sharma M, Khan AH and Bhat TA (2009) Assessment of mutagenicity of individual and combination treatments of gamma rays and MMS in broad bean (Vicia faba L.). Cytologia 74:235-241.

Shi JM, Guo JG, Li WJ, Zhang M, Huang L and Sun YQ (2010) Cytogenetic effects of low doses of energetic carbon ions on rice after exposures of dry seeds, wet seeds and seedlings. J Radiat Res 51:235-242.

Sousa JSI de, Peixoto AM and de Toledo FF (1995) Enciclopédia Agrícola Brasileira A-B. Editora da Universidade de São Paulo, São Paulo, 508 p.

Todoriki S and Toru H (1999) DNA comet assay for rice seeds treated with low energy electrons ("soft-electrons"). Food Irradiation Japan 34:9-15.

Vasquez MR (2010) Combining the in vivo comet and micronucleus assays: A practical approach to genotoxicity testing and data interpretation. Mutagenesis 25:187-199.

Vaughan DA (1994) The Wild Relatives of Rice: A Genetic Resources Handbook. International Rice Research Institute, Manila, $137 \mathrm{p}$.

Villela IV, Lau A, Silveira J, Prá D, Rolla HC and Silveira J de D (2003) Bioensaios para o monitoramento de genotoxicidade Ambiental. In: da Silva J, Erdtmann B and Henriques JAP (eds) Genética Toxicológica. Alcance, Porto Alegre, pp 147-163.

Walter M and Marchesan E (2011) Phenolic compounds and antioxidant activity of rice. Braz Arch Biol Technol 54:371-377.

Wei LJ, Yang Q, XIA HM, Furusawa Y, Guan SH, Xin P and Sun YQ (2006) Analysis of cytogenetic damage in rice seeds induced by energetic heavy ions on-ground and after spaceflight. J Radiat Res 47:273-278.

Wyatt MD and Pittman DL (2006) Methylating agents and dna repair responses: methylated bases and sources of strand breaks. Chem Res Toxicol 19:1580-1594.

Associate Editor: Catarina S. Takahashi

License information: This is an open-access article distributed under the terms of the Creative Commons Attribution License (type CC-BY), which permits unrestricted use, distribution and reproduction in any medium, provided the original article is properly cited. 